\title{
Influence of Dehydrated Wheat/Rice Cereal Matrices on Probiotic Activity of Bifidobacterium animalis ssp. lactis BB-12 ${ }^{\oplus 5}$
}

\author{
Andreja Leboš Pavunc'® ${ }^{\top}$, \\ Lenkica Penava² $\oplus^{2}$ Jasmina \\ Ranilović ${ }^{\circledR}$, Jasna Novak ${ }^{\top}$, \\ Martina Banić $\oplus^{\oplus}$, Katarina \\ Butorac $^{1} \odot$, Emilija Petrović ${ }^{3} \oplus$, \\ Vesna Mihaljević-Herman ${ }^{3}$, \\ Krešo Bendelja ${ }^{4} \odot$, Ana Savić \\ Mlakar ${ }^{4} \oplus$, Ksenija Durgo ${ }^{5} \odot$, \\ Blaženka Kos ${ }^{1 *} \odot$ and \\ Jagoda Šuškovićl @ \\ 'University of Zagreb, Faculty of Food \\ Technology and Biotechnology, \\ Laboratory of Antibiotic, Enzyme, \\ Probiotic and Starter Culture \\ Technologies, Pierottijeva 6, 10000 \\ Zagreb, Croatia \\ 2Belupo, Pharmaceuticals \& Cosmetics \\ Inc., Nutraceuticals, Business \\ Development and Registration, I. \\ Savica 36, 10000 Zagreb, Croatia \\ ${ }^{3}$ Podravka, Research and Development, \\ Ante Starčevića 32, 48000 Koprivnica, \\ Croatia \\ ${ }^{4}$ University of Zagreb, Centre for \\ Research and Knowledge Transfer \\ in Biotechnology, Rockefellerova 10, \\ 10000 Zagreb, Croatia \\ 5University of Zagreb, Faculty of Food \\ Technology and Biotechnology, \\ Laboratory for Biology and Microbial \\ Genetics, Pierottijeva 6, 10000 Zagreb, \\ Croatia
}

Received: 21 November 2018 Accepted: 18 June 2019

\section{(c) (1) (8)}

*Corresponding author:

Phone: +38514605291

Fax: +38514836424

E-mail:bkos@pbf.hr

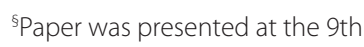
International Congress of Food Technologists, Biotechnologists and Nutritionists, 3-5 October 2018, Zagreb, Croatia

\section{SUMMARY}

Three novel dehydrated wheat/rice cereal functional products with an addition of well documented probiotic Bifidobacterium animalis ssp. lactis BB-12 $2^{\oplus}\left(\mathrm{BB}-12^{\circ}\right)$ were developed in Podravka factory for the infants older than 4 months: instant rice cereal, instant rice cereal with fruits and instant wheat cereal with vanilla. Notably, the number of viable $\mathrm{BB}-12^{\oplus}$ cells in each of the novel products was higher than the required minimal number of probiotic cells per gram of product $\left(10^{6} \mathrm{CFU} / \mathrm{g}\right)$ during the storage period of 106 weeks. Therefore, $\mathrm{BB}-12^{\oplus}$ strain recovery and genome stability were evaluated by strain-specific polimerase chain reaction and amplified fragment length polymorphism fingerprinting analysis. Further aim was to evaluate the influence of these three different cereal food matrices on specific probiotic properties of $\mathrm{BB}-12^{\circ}$ strain in vitro. Applied food matrices positively influenced the survival in the simulated conditions of the gastrointestinal tract and antagonistic activity against undesirable microorganisms, while no influence on auto- and coaggregation ability of $B$. animalis ssp. lactis $\mathrm{BB}-12^{\circ}$ was observed. Adhesion to extracellular matrix proteins and intestinal epithelial Caco-2 cells together with antibacterial activity emphasized competitive pathogen exclusion from Caco-2 cells by probiotic strain BB-12 ${ }^{\oplus}$.

Key words: Bifidobacterium, probiotics, dehydrated wheat/rice cereal products

\section{INTRODUCTION}

Probiotics are living microorganisms that, when administered in adequate amounts, confer a health benefit to the host (1). Probiotic bacteria are mostly members of Lactobacillus and Bifidobacterium genera. These genera are members of indigenous microbiota of humans and animals and are generally recognized as safe (GRAS) (2). An important probiotic property of bifidobacteria is the production of short-chain fatty acids (SCFAs), as well as breakdown of carbohydrates and proteins in the intestinal tract. It is believed that this feature is most valued because of the proven clinical effects of Bifidobacterium animalis ssp. lactis $\mathrm{BB}-12^{\circ}$ strain, in the prevention of diarrhoea caused by antibiotics, Clostridium difficile and rotavirus (3). Strain BB-12 ${ }^{\oplus}$ is one of the world's best-studied probiotic strains (4).

Desirable feature of probiotic strains is efficient binding to the intestinal epithelial cells and production of antimicrobial substances. However, to perform beneficial effects on human health, probiotics need to be applied in the high cell count. They have to survive food processing and gastrointestinal tract (GIT) transit, which is challenging for the food industry to find new alternatives for their incorporation in food. Probiotic functionality may even be enhanced after their application in food, since interaction with food ingredients can protect bacterial cells during the passage through the GIT (5).

The emergence of allergic diseases in infants is on a rise, often attributable to excessive hygiene resulting with insufficient exposure to microbes that are crucial in the development of the immune system (6). Intestinal microbiota is acquired by birth and there is significant difference in the gut microbiota composition of naturally delivered infants compared to infants delivered by caesarean section. Intestinal bacteria of the babies born 
by caesarean section originate from the surface of the mother's skin, instead of mother's vagina (7). Namely, intestinal microbiota of breast-fed infants mainly contains Bifidobacterium species, whereas intestinal microbiota of infants fed by industrial substitutes have higher number of Bacteroides, Clostridium and Lactobacillus bacteria. The intestinal microbiota affects the immune system and the lack of bifidobacteria is associated with the food allergies, e.g. Kirjavainen et al. (8) demonstrated the reduction of the allergic eczema by strain BB-12 ${ }^{\circledR}$, while Taipale et al. (9) showed increased resistance to the pathogens by BB-12 ${ }^{\circledR}$. Bifidobacteria beneficially affect health by indigestion of carbs not absorbed in the upper GIT, by producing vitamins, SCFAs and antimicrobial metabolites (10). Therefore, B. animalis ssp. lactis BB-12 ${ }^{\circledR}$ is commonly added probiotic strain to the infant formulas.

Previously, Hajduk et al. (11) investigated the probiotic properties of BB-12 ${ }^{\circledR}$ strain in cereal flakes enriched with inulin and the results showed increased viable cell count of lactic acid bacteria (LAB), while the number of enterobacteria and sulphite-reducing clostridia in the faecal and intestinal microbiota of mice was reduced. Cereal flakes and inulin had a protective role and promoted the BB- $12^{\circledR}$ strain survival under simulated GIT conditions. The main objective of this research is to determine the influence of three different matrices, i.e. instant rice cereal, instant rice cereal with fruits - apple, peach, pear and apricot, and instant wheat cereal with vanilla on probiotic properties of BB-12 ${ }^{\circledast}$. Genotypic characterisation and the functionality of $\mathrm{BB}-12^{\circledR}$ in the products was verified through the research of antibiotic susceptibility, survival in simulated GIT conditions, deconjugation activity to bile salts, assimilation of cholesterol, microbial antagonism and bacteriocinogenic activity. In addition, adhesion properties of BB$-12^{\circledR}$ strain on Caco- 2 cell line and proteins of extracellular matrix and competitive exclusion of test-microorganisms were investigated.

\section{MATERIALS AND METHODS}

\section{Dehydrated wheat/rice cereal products with a probiotic $B B-12^{\circledR}$}

We evaluated the functional properties of probiotic strain Bifidobacterium animalis ssp. lactis BB- $12^{\circledR}$ incorporated in dehydrated wheat/rice cereal products developed on a pilot scale, namely instant rice cereal, instant rice cereal with fruit and instant wheat cereal with vanilla, produced in Podravka d.d., Koprivnica, Croatia. Novel probiotic products contain $0.25 \%(\mathrm{~m} / \mathrm{m})$ PROBIO-TEC ${ }^{\circledR}$ BB-12 ${ }^{\circledR}$ strain (Chr. Hansen Holding $A / S$, Hoersholm, Denmark) in lyophilized form. Dehydrated instant rice cereal contains rice flour, vitamins (thiamine mononitrate, riboflavin, pyridoxine hydrochloride, L-ascorbic acid, DL-alpha tocopherol acetate, folic acid and nicotinamide) and iron(III) pyrophosphate. Dehydrated instant rice cereal with fruit contains follow-on formulae, rice grits, partially demineralized whey powder, inulin, maltodextrin, fruits (apple, peach, pear and apricot mash), skimmed milk, calcium lactate and vitamins ( $\beta$-carotene, thiamine mononitrate, riboflavin, pyridoxine hydrochloride, L-ascorbic acid, colecalciferol, DL-alpha tocopherol acetate, folic acid and niacin). Dehydrated instant wheat cereal with vanilla contains follow-on formulae, wheat grits, partially demineralized whey powder, skimmed milk, maltodextrin, wheat flour, starch, vitamins ( $\beta$-carotene, thiamine mononitrate, riboflavin, pyridoxine hydrochloride, L-ascorbic acid, colecalciferol, DL-alpha tocopherol acetate, folic acid and niacin) and vanilla flavouring.

Survival of probiotic strain BB-12 ${ }^{\circledR}$ in novel products during 24 months of storage at room temperature was determined by the agar plate method using transgalctosylated oligiosaccharide (TOS)-propionate agar (Merck, Darmstadt, Germany). The plates were incubated anaerobically for $72 \mathrm{~h}$ at $37^{\circ} \mathrm{C}$.

\section{$P C R$ and $A F L P$ identification of $B B-12^{\circledR}$ in novel products}

BB- $12^{\circledR}$ colonies grown on TOS-propionate agar plates were collected and grown in MRS broth medium (Biolife, Milan, Italy) for $18 \mathrm{~h}$. DNA was isolated from $1.5 \mathrm{~mL}$ of BB-12 ${ }^{\circledR}$ overnight cultures using the method of Gardiner et al. (12), while polymerase chain reaction (PCR) with specific primers for Bifidobacterium species was performed as described by Kaufmann et al. (13). The extracted DNA was then used as a template in subsequent PCR amplifications, which were performed in a total volume of $50 \mu \mathrm{L}$ in a DNA Mastercycler (Eppendorf Scientific Inc., Hamburg, Germany). PCR mixtures contained $4 \mathrm{ng} / \mu \mathrm{L}$ of template DNA, $10 \times$ Taq polymerase buffer (Gibco BRL Life Technologies, Burlington, Ontario, Canada), each deoxynucleoside triphosphate (Thermo Fisher Scientific, Waltham, MA, USA) at a concentration of $0.2 \mu \mathrm{M}, 1 \mathrm{U}$ of Taq DNA polymerase (Boehringer $\mathrm{GmbH}$, Mannheim, Germany), and each primer at a concentration of $1 \mu \mathrm{M}$. A Bifidobacterium genus-specific target sequence in the $\mathrm{V} 9$ variable region of the 16S rRNA (5'-CGGGTGCTGCCCACTTTCATG-3') was used to identify BB-12 ${ }^{\circledR}$. DNA was amplified for 30 cycles by using the following conditions: denaturation at $94{ }^{\circ} \mathrm{C}$ for $40 \mathrm{~s}$, annealing at $52{ }^{\circ} \mathrm{C}$ for $1 \mathrm{~min}$, and polymerization at $72{ }^{\circ} \mathrm{C}$ for 3 $\min$. The initial denaturation was performed at $95^{\circ} \mathrm{C}$ for $5 \mathrm{~min}$, and a final extension step at $72^{\circ} \mathrm{C}$ for $8 \mathrm{~min}$ was also used. The PCR products $(10 \mu \mathrm{L})$ were analysed on a $1.5 \%(w / V)$ agarose (Fisher Scientific, Fair Lawn, NJ, USA) gel with $1 \times$ TAE buffer (40 $\mathrm{mM}$ Tris acetate, $1 \mathrm{mM}$ EDTA, $\mathrm{pH}=8$ ) and ethidium bromide staining. An O'GeneRuler 100-bp DNA ladder (Thermo Fisher Scientific, Rochester, NY, USA) and $\lambda$ HindIII were used as molecular size standards. Gels were run for approx. $2 \mathrm{~h}$ at $55 \mathrm{~V}$, and the DNA was visualized by MiniBisPro (DNR Bio-Imaging Systems LTD, Jerusalem, Israel).

Bacterial strain identification was confirmed by DNA fingerprinting technique amplified fragment length polymorphism (AFLP) provided by an independent institution Belgian Coordinated Collection of Microorganisms (BCCM ${ }^{\mathrm{TM}}$ )/ LMG Bacteria Collection Identification Service, Ghent University, Ghent, Belgium (14). Clustering of the patterns was done using the Dice coefficient and the UPGMA algorithm (15). 


\section{Survival of $B B-12^{\circledR}$ in simulated gastric and} small intestinal juice

Cumulative effect of the simulated gastric and small intestinal juice on the survival of BB- $12^{\circledR}$ strain was investigated according to Hajduk et al. (11). Samples were pure lyophilized culture of BB- $12^{\circledR}$ and BB- $12^{\circledR}$ in instant rice cereal, instant rice cereal with fruit and instant wheat cereal with vanilla. Simulated gastric juice was prepared by suspending pepsin ( $3 \mathrm{~g} / \mathrm{L}$; Sigma-Aldrich, Merck, St. Louis, MO, USA) in a sterile sodium chloride solution ( $0.5 \%$; Kemika, Zagreb, Croatia) and $\mathrm{pH}$ was adjusted to 2.5 with concentrated $\mathrm{HCl}$ (Kemika). Simulated small intestinal juice was prepared by suspending pancreatin ( $1 \mathrm{~g} / \mathrm{L}$; Fluka Biochemica, Buchs, Switzerland) and bile salts ( $1.5 \mathrm{~g} / \mathrm{L}$ oxgall; Difco, Detroit, $\mathrm{MI}$, USA). Samples were taken every hour during the treatment with gastric juice and every $2 \mathrm{~h}$ during treatment with small intestinal juice. The viable cell count was determined after $24 \mathrm{~h}$ of anaerobic incubation at $37^{\circ} \mathrm{C}$. The results are expressed in log $\mathrm{CFU} / \mathrm{mL}$ as the mean of three replicates.

\section{Quantitative determination of the bile salt hydrolase activity and cholesterol assimilation}

The ability of probiotic strains to hydrolyze bile salts is included among the criteria for probiotic strain selection, therefore the bile salt hydrolase activity was determined by quantification of the amount of cholic acid liberated from conjugated bile salt sodium taurocholate (Difco, Detroit, MI, USA) using solvent extraction method during $24 \mathrm{~h}$ of incubation. The BB- $12^{\circledR}$ capability to assimilate cholesterol (AppliChem, Darmstadt, Germany) in MRS broth was evaluated by the modified o-phthalaldehyde method (16). The amount of the cholesterol was determined in the supernatant, in the washing buffer, where precipitated cholesterol was redissolved, and in the cell extract after cell disruption to obtain assimilated cholesterol after $24 \mathrm{~h}$ of incubation in MRS containing $3 \mathrm{mg} / \mathrm{mL}$ of oxgall (Difco) and $0.2 \mathrm{mg} / \mathrm{mL}$ of cholesterol (17). Samples for these methods were: lyophilized pure BB-12 ${ }^{\circledR}$ strain and wheat/rice cereal product (instant rice cereal with or without fruit and instant wheat cereal with vanilla), cultivated in MRS broth. Absorbance was read at $540 \mathrm{~nm}$ using an automatic microplate reader TECAN INFINITE ${ }^{\circledR} 200$ PRO (Männedorf, Switzerland). A standard curve of absorbance versus cholesterol concentrations was generated and finally the cholesterol assimilated by probiotic BB- $12^{\circledR}$ samples was calculated as percentage according to the following equation:

Cholesterol assimilation $=\left(\left(c_{0}-c_{24}\right)-c(\right.$ precipitated $\left.) / c_{0}\right) \cdot 100 / 1 /$ where $c_{0}$ is cholesterol concentration at $0 \mathrm{~h}, c_{24}$ is cholesterol concentration after $24 \mathrm{~h}$ and $c$ (precipitated) is the concentration of cholesterol precipitated in the solution.

\section{Antibiotic susceptibility testing}

Antibiotic susceptibility was examined by agar disc diffusion method using test discs (Oxoid Ltd., Basingstoke, UK) and E test strips (M.I.C.Evaluator ${ }^{\mathrm{TM}}$, Oxoid Ltd) according to Leboš
Pavunc et al. (18). Briefly, overnight grown culture of BB-12 ${ }^{\circledR}$, diluted to give viable cell count of approx. $10^{8} \mathrm{CFU} / \mathrm{mL}$, was inoculated into $12 \mathrm{~mL}$ of MRS agar. Next, susceptibility test disks (Oxoid, Ltd) of eight different antibiotics were placed aseptically on the MRS agar and incubated for $24 \mathrm{~h}$. The diameters of the inhibition zones were measured and an average of three readings was calculated.

\section{Antimicrobial activity}

Antimicrobial activity was tested by agar-well diffusion assay performed according to Kos et al. (19) and by microplate growth inhibition assay described by Beganović et al. (20) with slight modifications. Samples for agar-well diffusion were twofold dilutions of lyophilized pure culture of BB- $12^{\circledR}$ strain and wheat/rice cereal products instant rice cereal, instant rice cereal with fruit and instant wheat cereal with vanilla. Antagonistic activity of BB-12 ${ }^{\circledR}$ strain, evaluated by the agar-well diffusion assay, was expressed as the diameter of the inhibition zones. The antimicrobial activity of the supernatants obtained after cultivation of lyophilized pure culture of BB-12 ${ }^{\circledR}$ strain and from wheat/rice cereal products, instant rice cereal with or without fruit and instant wheat cereal with vanilla in MRS broth was determined by microplate growth inhibition assay. Settings for the growth curve/turbidity analysis using an Infinite 200 PRO multimode plate reader Infinite 200 PRO (Tecan Inc, Morrisville, NC, USA) were as follows: absorbance measurement wavelength $620 \mathrm{~nm}$, number of flashes 1, temperature range $35-37^{\circ} \mathrm{C}$, shaking amplitude $3 \mathrm{~mm}$, shake duration (orbital normal) $10 \mathrm{~s}$, kinetic interval $3600 \mathrm{~s}$, and total measurement time $6 \mathrm{~h}$. The Falcon ${ }^{\circledR} 96$-well flat-bottom plate with low evaporation lid (Falcon, Corning Inc., Durham, NC, USA) was used to prevent evaporation of the liquid and well-to-well contamination. The obtained $A_{620 \mathrm{~nm}}$ values were plotted against time and used to calculate the antibacterial activity of the samples against test microogranisms.

\section{Autoaggregation and coaggregation assays}

Autoaggregation assays were performed as described previously (21). Bacteria were grown in MRS broth, harvested by centrifugation at $1771 \times \mathrm{g}$ for $10 \mathrm{~min}$ in Eppendorf centrifuge 5804R (Hamburg, Germany), and washed twice with phosphate-buffered saline (PBS; pH=7.4; Gibco, Paisley, Scotland, UK). Washed bacterial cells were resuspended in PBS to an adjusted absorbance $\left(A_{600 \mathrm{~nm}}\right)$ of 1 and autoaggregation was determined over $5 \mathrm{~h}$ using microplate reader LKB 5060-006 (LKB Vertriebs GmbH, Vienna, Austria). The autoaggregation percentage is expressed as:

$$
\text { Autoaggregation }=\left(1-\left(A_{t} / A_{0}\right)\right) \cdot 100
$$

where $A_{\mathrm{t}}$ represents the absorbance at time $t=1,2,3,4$ or $5 \mathrm{~h}$ and $A_{0}$ the absorbance at $t=0 \mathrm{~h}$. The percentage of coaggregation was calculated using the equation described by Kos et al. (19), where $x$ and $y$ represent each of the two bacterial strains in the experiment, and $(x+y)$ their mixture: 


$$
\text { Coaggregation }=\frac{\left(\frac{A_{\mathrm{x}}+A_{\mathrm{y}}}{2}\right)-A(\mathrm{x}+\mathrm{y})}{A \mathrm{x}+A \mathrm{y} / 2} \cdot 100
$$

Samples for these methods were BB- $12^{\circledR}$ strains isolated from lyophilized pure culture and from wheat/rice cereal products; instant rice cereal with or without fruit and instant wheat cereal with vanilla.

\section{Adhesion experiments}

Caco-2 cells were seeded onto 48-well plate in a final volume of $230 \mu \mathrm{L}$ of Dulbecco's modified medium/Ham's F-12 (DMEM/ F12; Capricorn Scientific GmbH, Ebsdorfergrund, Germany) supplemented with $10 \%$ fetal bovine serum (FCS; Thermo Fisher Scientific, Rochester, NY, USA) and L-glutamine. After formation of a monolayer, the Caco- 2 cells were routinely inoculated with bacterial suspensions at multiplicity of infection (MOI) 10 and 100 for 1, 4 and $12 \mathrm{~h}$ with slow agitation at $2 \mathrm{rpm}$ (Hi/Lo Rocker; IBI Scientific, Dubuque, IA, USA). In brief, $2.3 \cdot 10^{9} \mathrm{CFU} / \mathrm{mL}$ BB-12 ${ }^{\circledR}$ bacteria were washed twice with PBS at $3000 \times g$ for 15 min in Eppendorf centrifuge 5804R at room temperature. After discarding the supernatant, the pellet was suspended in $500 \mu \mathrm{L}$ of $5 \mu \mathrm{M}$ of fluorescent label 5(6)-carboxyfluorescein N-hydroxysuccinimide ester (CFSE; BioLegend, San Diego, CA, USA) in PBS and incubated in thermomixer (Eppendorf Scientific Inc, Hamburg, Germany) at $37^{\circ} \mathrm{C}$ for $60 \mathrm{~min}$. BB-12 ${ }^{\circledR}$ bacterial cells were then washed twice with PBS and 0.5\% BSA (Sigma Aldrich, Merck, Schnelldorf, Germany). The remaining pellet was suspended in $1 \mathrm{~mL}$ of medium and the appropriate volume of the suspension was added to each well. After incubation period, the non-adherent bacteria were washed twice with PBS and the cells with adherent bacteria were fixed in $4 \%$ formaldehyde, $\mathrm{pH}=7.4$, at $37^{\circ} \mathrm{C}$ for $15 \mathrm{~min}$. After fixation and subsequent washing with PBS, the cells were stained with 4,6-diamidino-2-phenylindole (DAPI; Thermo Fisher Scientific, Rochester, NY, USA). Images of Caco- 2 and BB- $12^{\circledR}$ cells were acquired using an EVOS FLc Cell Imager (Thermo Fisher Scientific, Waltham, MA, USA). In parallel, to evaluate the potential effect of the indigestible resistant starch, available in human colon, on $\mathrm{BB}-12^{\circledR}$ adhesion, binding of the BB- $12^{\circledR}$ to Caco- 2 cell line in the presence of the two different starch mass fractions 1 and $10 \%$ was assessed.

Human fibronectin (BD BioCoat; BD Biosciences, Erembodegem, Belgium), type I collagen (Biocoat, Coventry, UK) and laminin (BD BioCoat; BD Biosciences) immobilised on 96-well flat-bottom plates were used in experiments of $B B-12^{\circledR}$ binding to immobilised extracellular matrix proteins according to the method described by Uroić et al. (22). Bifidobacterium BB-12 ${ }^{\circledR}$ cell suspension $\left(A_{620 \mathrm{~nm}}=1.0\right)$, grown until late exponential phase, was incubated overnight at $4{ }^{\circ} \mathrm{C}$. After removing the nonadhered bacteria by three washes with $200 \mathrm{~mL}$ of PBS and 0.05 $\%$ Tween 20, the plates were dried and the adhered bacterial cells were detected by staining with $1 \mathrm{mg} / \mathrm{mL}$ crystal violet (Merck, Darmstadt, Germany) for 45 min. After washing, the colourant was released with $50 \mathrm{mM}$ sodium citrate buffer $(\mathrm{pH}=4.0)$ and the absorbance at $620 \mathrm{~nm}$ was measured by a microplate reader (LKB Vertriebs $\mathrm{GmbH}$ ). The effect of protease treatment was performed by incubating bacterial cells at $A_{620 \mathrm{~nm}}=1.0$ in 1 $\mathrm{mL}$ of PBS with $100 \mathrm{mg} / \mathrm{mL}$ of proteinase $\mathrm{K}$ (Invitrogen ${ }^{\mathrm{TM}}{ }$, Carlsbad, CA, USA) at $37^{\circ} \mathrm{C}$ for $1 \mathrm{~h}$. After incubation, the proteinase was inactivated by the addition of $1 \mathrm{mM}$ phenylmethylsulfonyl fluoride (PMSF) followed by three washes with $1 \mathrm{mM}$ PMSF in PBS. Bacterial cells were resuspended in PBS to $A_{620 \mathrm{~nm}}=1.0$ and used for binding assays. Control bacterial cells were handled exactly as the treated bacterial cells but without the addition of proteinase $\mathrm{K}$. All the experiments were repeated three times and the results were expressed as mean values of three independent trials \pm standard deviation (S.D.).

\section{Pathogen exclusion assay on Caco-2 cell line}

To assess the ability of the BB- $12^{\circledR}$ strain to exclude enteropathogens Salmonella enterica serovar Typhimurium FP1 and Escherichia coli 3014, exclusion and adhesion assay on Caco-2 cell line was performed as described by Uroić et al. (22) and Banić et al. (23). The Caco-2 cells were grown in 24-well flat-bottom tissue culture plates (Falcon, Corning Inc) until confluent differentiated monolayers were obtained. Before competitive exclusion assay, the Caco-2 monolayers were carefully rinsed three times with PBS ( $\mathrm{pH}=7.4)$. Routinely cultivated $\mathrm{BB}-12^{\circledR}$ and enteropathogenic bacterial cells were harvested and suspended in PBS ( $\mathrm{pH}=7.4$ ) to reach $A_{620 \mathrm{~nm}}=1$ (approx. $10^{9} \mathrm{CFU} / \mathrm{mL}$ ). After $1 \mathrm{~h}$ of incubation of $\mathrm{BB}-12^{\circledR}$ at $37^{\circ} \mathrm{C}$, Caco- 2 monolayers were gently washed three times with PBS ( $\mathrm{pH}=7.4)$. Next, the enteropathogenic cells were added and Caco-2 cells were incubated for additional $1 \mathrm{~h}$ at $37^{\circ} \mathrm{C}$. Both 1.0-mL aliquots of the enteropathogen or DMEM were used as the control. Nonadhered bacterial cells were removed by washing with PBS $(\mathrm{pH}=7.4)$. The Caco- 2 cells were then lysed by the addition of $0.25 \%$ (V/V) Triton X-100 (AppliChem) at $37^{\circ} \mathrm{C}$ for 10 min in order to collect the adherent bacterial cells, and the total numbers of viable adhering BB- $12^{\circledR}$, E. coli and S. Typhimurium were determined by spot plate method on MRS, Rapid (Biorad, Dubai, United Arab Emirates) and XLD (Biolife, Milano, Italy) agar plates, respectively.

\section{Statistical analyses}

All experiments were performed in triplicate and the results were expressed as mean values of three independent trials \pm standard deviation. Statistical significance was appraised by one-way analysis of variance. Pairwise differences between the mean values of groups were determined by the Tukey's honestly significant difference (HSD) test for pairwise comparisons (24). The differences between treatments that were subsequently described as significant were determined at $\mathrm{p}<0.05$.

\section{RESULTS AND DISCUSSION}

In order to exert the health promoting effects, probiotic preparations should contain live bacterial cell counts higher than $10^{6} / \mathrm{g}$ of the product, as recommended by FAO/WHO $(25,26)$. Therefore, the initial number of BB- $12^{\circledR}$ cells in wheat/ 
rice cereal products was set up to $2.71 \cdot 10^{7} \mathrm{CFU} / \mathrm{g}$. Moreover, the number of viable probiotic cells determined in the 106th week was above the required minimum counts for probiotic products $\left(10^{6} / \mathrm{g}\right.$ of product). This storage period is actually one year longer than the commonly accepted dehydrated wheat/rice cereal product expiry date (Fig. 1a). Besides storage conditions, the product manufacturing process strongly impacts the viability of the bacterial strains, influencing probiotic stability and properties. Therefore, to confirm the BB$12^{\circledR}$ strain presence and strain purity after its application in the

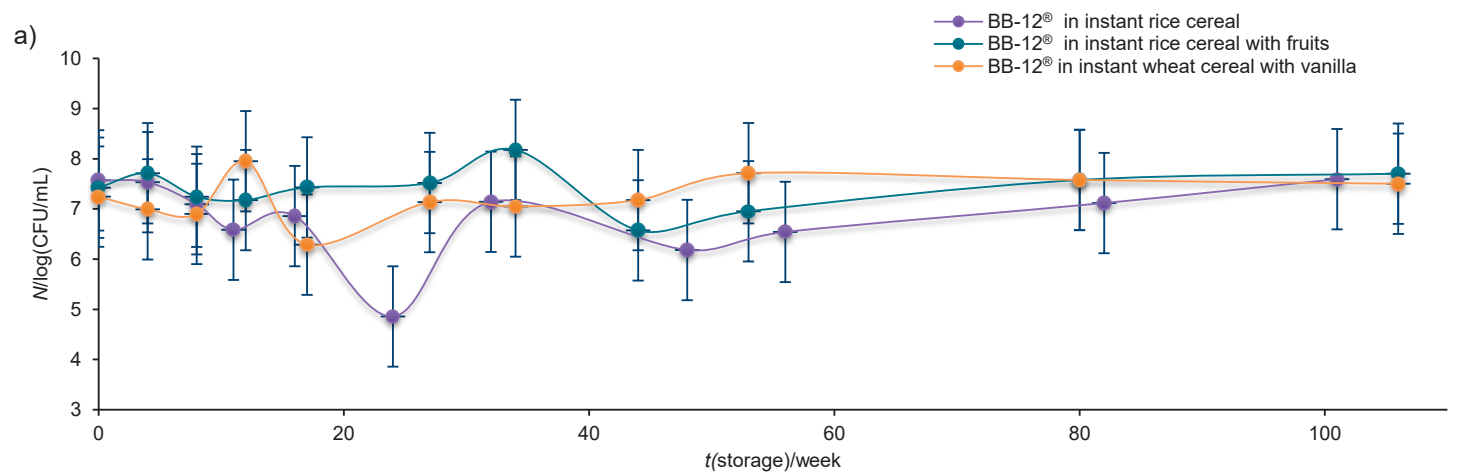

b)

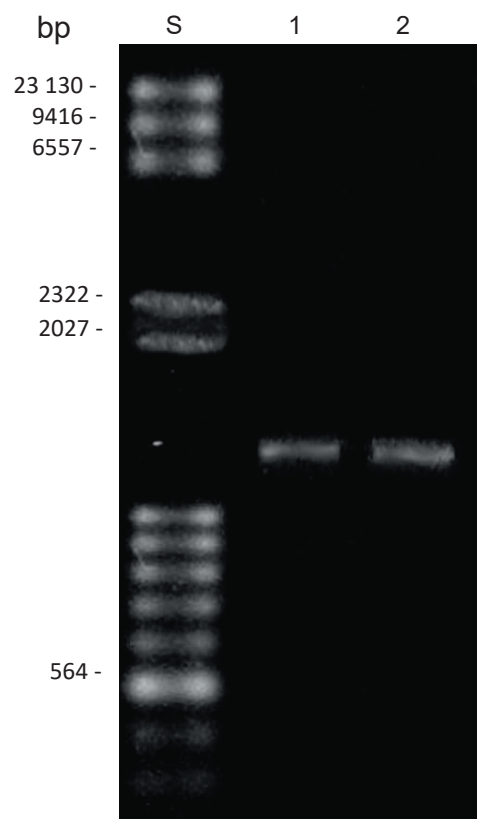

developed products, validated genotypic methods were employed. Probiotic strain BB-12 ${ }^{\circledR}$ was isolated from the respective products on selective TOS-propionate agar medium. For rapid quality control of the strain, in a culture or in the product, single bacterial colonies were collected for the strain identification and characterisation, where lyophilized pure culture of BB- $12^{\circledR}$ strain was used as a control. PCR method performed with Bifidobacterium species-specific primers confirmed the presence of a single-stranded DNA, either from the bacterial culture recovered from the instant rice cereal product or from freeze-dried pure culture, which corresponded to the bacteria of the Bifidobacterium genus (Fig. 1b). Next, reidentification of the bacterial strain isolated from the instant rice cereal was carried out by DNA fingerprinting AFLP method provided by BCCM Identification Service, University of Ghent (Ghent, Belgium). Cluster analysis of the AFLP ${ }^{\mathrm{TM}}$ DNA fingerprint of the isolated DNA sample (assigned ID 15042) with the reference AFLP ${ }^{\text {тм }}$ DNA fingerprints of the lactic acid bacteria taxa, including bifidobacteria as currently available in BCCM database (14), confirmed the isolated bacterial culture from the novel product as Bifidobacterium animalis (Fig. 1c). Additionally, since the

c)

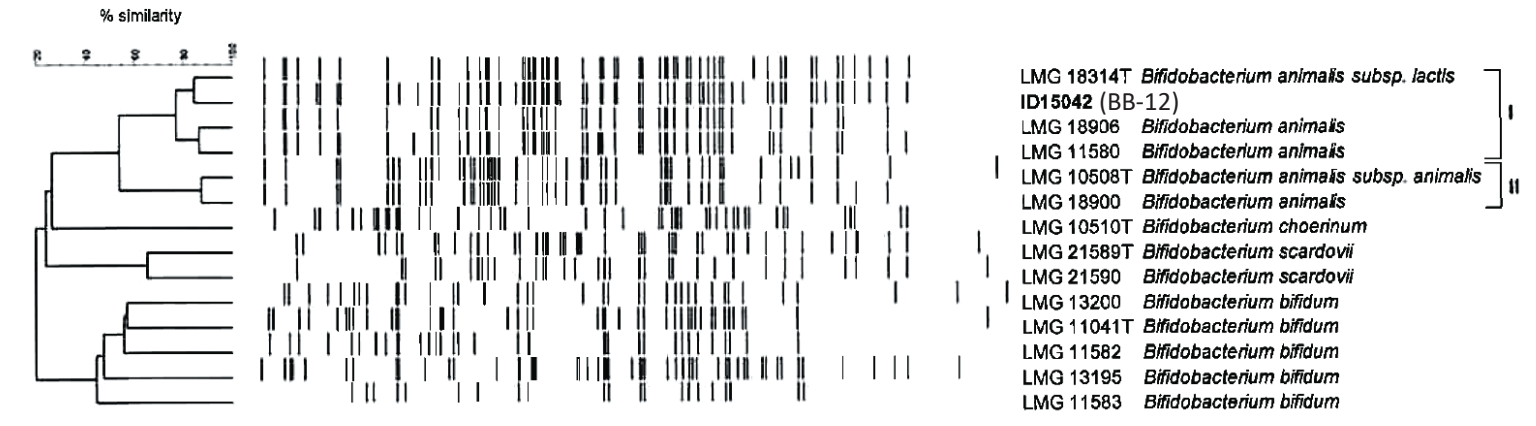

Fig. 1. The presence of viable Bifidobacterium animalis ssp. lactis BB-12 ${ }^{\circledR}$ cells in dehydrated wheat/rice cereal product is confirmed: a) during long term storage for 106 weeks. The results are mean values of three independent experiments and error bars represent standard deviations, $b$ ) by polymerase chain reaction (PCR) with specific primers for Bifidobacterium strains. $\mathrm{S}=$ standard $\lambda$ HindIII and Gene ruler $100 \mathrm{bp}, 1=\mathrm{lyophilized}$ BB- $12^{\oplus}$ culture, $2=\mathrm{BB}-12^{\circledR}$ culture isolated from instant rice cereal, and c) by AFLPTM DNA fingerprinting profile of $B$. animalis ssp. lactis BB-12 ${ }^{\circledR}$ (ID 15042) compared with BCCM reference and phylogenetically related Bifidobacterium species (type strains are indicated with T) (BCCM ${ }^{\text {TM}} / L_{M M G}$ Identification Service, Ghent University, Ghent, Belgium) 
species $B$. animalis encompasses two subgroups: subgroup containing the type strains of $B$. animalis ssp. lactis, and subgroup II, containing the type strain of $B$. animalis ssp. animalis, as demonstrated by AFLP ${ }^{\text {тM }}$ (Fig. 1c), it was important to group the presumptive BB-12 ${ }^{\circledR}$ isolate from the product. The obtained dendrogram clearly demonstrated that the applied BB- $12^{\circledR}$ is genetically related to the strains of subgroup I B. animalis ssp. lactis.

According to EFSA (European Food Safety Authority), bacterial products intended for use either as food or feed additives must be examined to establish the susceptibility of the component strain(s) to antibiotics (27). In the case of Bifidobacterium, the minimum inhibitory concentration of each of the antibiotics: ampicillin, vancomycin, gentamicin, streptomycin, erythromycin, clindamycin, tetracycline and chloramphenicol must be determined. Antibiotic susceptibility of the BB-12 ${ }^{\circledR}$, both as lyophilized pure culture or a culture applied to the products was monitored by the agar diffusion method and $E$ test, and their profiles coincided, confirming a lack of the influence of the product matrices on the antibiotic susceptibility of the BB-12 ${ }^{\circledR}$. The results were in correlation with EFSA recommendation, except for aminoglycosides, which are probably inactivated in acidic medium due to the BB-12 ${ }^{\circledR}$ production of acetic and lactic acid (data not shown) (28).

The influence of instant rice cereal with or without fruit and instant wheat cereal with vanilla matrices on the BB-12 ${ }^{\circledR}$ survival in the GIT was evaluated. The main obstacle for surviving in the GIT conditions is low $\mathrm{pH}$ of the stomach, bile salts and digestive enzymes. Therefore, the survival of BB-12 ${ }^{\circledR}$ strain, as lyophilized pure culture and culture from instant rice or wheat cereal products, was examined in simulated GIT conditions (Fig. 2). Number of BB- $12^{\circledR}$ cells in all wheat/ rice cereal products at the end of the study was up to 2.5 logarithmic units higher than the number of live cells in the lyophilized culture. Therefore, instant wheat/rice cereal matrices have protective effect when exposing BB- $12^{\circledR}$ cells to rigorous stress conditions that are present in the GIT. However, there was no significant difference observed in the BB-12 ${ }^{\circledR}$ cell survival in simulated GIT among the three matrices. This

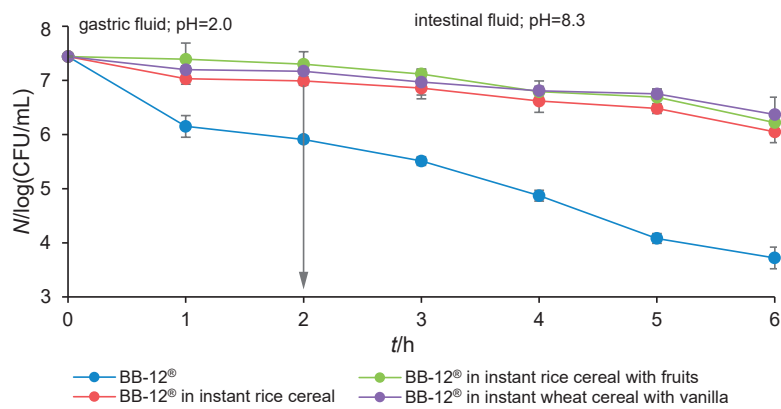

Fig. 2. Survival of Bifidobacterium animalis ssp. lactis BB-12 ${ }^{\circledR}$ in the dehydrated wheat/rice cereal products exposed to simulated gastrointestinal tract conditions (arrow indicates the change in in vitro conditions: after $2 \mathrm{~h}$ in simulated gastric fluid at $\mathrm{pH}=2.0$ followed by 4-hour incubation in simulated intestinal fluid at $\mathrm{pH}=8.3$ ). The results are expressed as mean values of three independent experiments and error bars represent standard deviations is in accordance with the results of Jungersen et al. (4), who have summarised investigations related to exposure of Bifidobacterium strains to low $\mathrm{pH}$, gastric juice and bile salts and reported that BB-12 ${ }^{\circledR}$ exhibited higher gastric acid and bile tolerance than other Bifidobacterium strains. Similarly, dos Santos et al. (29) in the recently published work observed a higher survival of BB- $12^{\circledR}$ when applied in table spreads as food matrix than of $\mathrm{BB}-12^{\oplus}$ culture alone, when exposed to similar in vitro gastrointestinal simulated conditions. High BB-12 ${ }^{\circledR}$ acid tolerance is probably due to the induction of $\mathrm{H}^{+}$-ATPase, an enzyme complex involved in maintaining intracellular $\mathrm{pH}$ homeostasis in bacteria (4).

The high concentration of bile salts in the intestine, due to the high inhibition activity against Gram-positive microorganisms, is an obstacle for the probiotic bacteria to colonize ileum terminalis. One of the mechanisms of bacterium resistance to bile salts is their deconjugation by hydrolase enzyme. Therefore, cell growth of BB-12 ${ }^{\circledR}$ strain, as lyophilized pure culture and culture in wheat/rice cereal products, in the presence of bile salts was examined. The deconjugation of sodium salt of taurocholic acid as the most common bile salt in the human bile was also tested by quantitative determination of the bile salt hydrolase activity (Table 1 ). Additionally, cholesterol assimilation of BB-1 $2^{\circledR}$ strain was examined in both lyophilized pure culture and in the culture recovered from wheat/rice cereal products after $24 \mathrm{~h}$ of cultivation in the presence of bile salts (data not shown). Probiotic strain BB- $12^{\circledR}$ probably produces bile acid hydrolase, since it exhibits deconjugation activity during the growth in a nutrient medium supplemented with $2 \mathrm{mg} / \mathrm{mL}$ sodium taurocholate. This mechanism is potentially responsible for the defence action of BB- $12^{\circledast}$ cells against bile salts. BB- $12^{\circledR}$ produces bile salt hydrolase, an enzyme that catalyses bile salt deconjugation and consequently provides an advantage for the cell as it allows a quick response to high bile salt concentrations and thus facilitates the viable passage from the small intestine to the large intestine (4). Next, no significant difference was observed among the isolates from three cereal products, although BB- $12^{\circledR}$ cells isolated from the instant rice cereal with fruit exhibited a slightly higher bile acid hydrolase activity (Table 1 ). After 24 h of BB- $12^{\circledR}$ growth in the presence of cholesterol and bile salts, the cells from lyophilized pure culture removed about $55 \%$ of the cholesterol from the nutrient medium. Approx. $30 \%$ of the cholesterol was present in the extract of the cells, indicating not only the cholesterol coprecipitation with the deconjugated bile salts (approx. $25 \%$ ), but also its assimilation. Conversely, BB$-12^{\circledast}$ cells from instant rice cereal assimilated up to $50 \%$ of total cholesterol, while during the growth of probiotic $45 \%$ of cholesterol was precipitated in solution. BB- $12^{\circledR}$ cells from the instant rice cereal with fruit removed about $90 \%$ of the cholesterol from the nutrient medium. As $48 \%$ cholesterol was found in the extract of the cells, it means that this product matrix increased the assimilation of cholesterol by $18 \%$. Finally, BB- $12^{\circledR}$ cells from the instant wheat cereal with vanilla removed $82 \%$ of the cholesterol from the nutrient medium. 
Table 1. Growth $\left(A_{620 \mathrm{~nm}}\right)$ and bile salt hydrolase activity of Bifidobacterium animalis ssp. lactis BB-12 ${ }^{\circledR}$ from wheat/rice cereal products after $24 \mathrm{~h}$ of cultivation at $37^{\circ} \mathrm{C}$ in MRS broth supplemented with $2 \mathrm{mg} / \mathrm{mL}$ of sodium salt of taurocholic acid (TCA)

\begin{tabular}{|c|c|c|c|}
\hline Sample & $A_{620 \mathrm{~nm}}$ & $\gamma($ cholic acid $) /(\mathrm{g} / \mathrm{L})$ & $w($ deconjugated TCA $) / \%$ \\
\hline BB-12 ${ }^{\circledR}$ & $(0.40 \pm 0.01)^{\mathrm{a}}$ & $(0.26 \pm 0.02)^{b}$ & $(13.0 \pm 1.5)^{\mathrm{ab}}$ \\
\hline BB-12 $2^{\circledast}(\mathrm{IRC})$ & $(0.42 \pm 0.03)^{\mathrm{a}}$ & $(0.27 \pm 0.01)^{\mathrm{b}}$ & $(13.5 \pm 0.7)^{\mathrm{ab}}$ \\
\hline BB- $12^{\circledR}$ (IRCF) & $(0.41 \pm 0.07)^{\mathrm{a}}$ & $(0.5 \pm 0.02)^{\mathrm{a}}$ & $(15.0 \pm 1.3)^{\mathrm{a}}$ \\
\hline BB-12 ${ }^{\circledR}($ IWC) & $(0.39 \pm 0.05)^{\mathrm{a}}$ & $(0.25 \pm 0.03)^{\mathrm{b}}$ & $(13.0 \pm 0.5)^{b}$ \\
\hline
\end{tabular}

IRC=instant rice cereal, IRCF=instant rice cereal with fruit, IWC=instant wheat cereal with vanilla. The results are expressed as mean value \pm standard deviation of three separate experiments. Different letters in superscript indicate statistically significant difference among the data across the same column (Tukey's HSD test, $\mathrm{p}<0.05, N=3$ )

As $43 \%$ cholesterol was found in the extract of the cells, it means that this product matrix increased the assimilation of cholesterol by $13 \%$. As previously commented, bile salts disorganize the structure of the cell membrane and trigger DNA damage if Gram-positive bacteria do not have intrinsic resistance mechanisms against their deleterious action. Bifidobacteria can progressively adapt to the presence of bile salts and probably have evolved specific defence mechanisms, which include action of a variety of proteins devoted to the efflux of bile salts or protons, to modify sugar metabolism or to prevent protein misfolding. Bile response is a multifactorial phenomenon connecting processes addressed towards detoxification of bile and counteracting the effect on bacterial structures. Besides, protection against oxidative damage and global glycolytic reorganizations are other mechanisms that might be employed to counteract cellular damage caused by bile salts (30).

Pathogen exclusion is important aspect of probiotic mode of action. It is facilitated through the production of inhibitory substances, toxin degradation, competition for nutrients and sites of adherence, and induction of immune responses (4). The inhibition of Gram-negative bacteria is mainly due to the production of common metabolites such as organic acids, while different peptides and bacteriocins are of importance in the inhibition of Gram-positive microorganisms. Bacteriocins are antimicrobial peptides with activity spectra against closely related Gram-positive bacteria, while the producing cells are immune to their action. Therefore, antibacterial activity of BB- $12^{\circledR}$ strain, as purified lyophilized cultures and culture in wheat/rice cereal products, was examined towards test-microorganisms that are potential food contaminants and pathogens, using the agar-well diffusion assay and the turbidimetric method (Fig. 3). Higher inhibition activity was obtained with cells in the pure lyophilized culture, which may be caused by difficulty of antimicrobial metabolite diffusion trough the production matrix (data not shown). Significant difference in the antimicrobial activity of the supernatants from the instant rice cereal and instant wheat cereal with vanilla against test microorganism Bacillus subtlis ATCC 6633 and supernatant from the instant rice cereal against test microorganism S. Typhimurium FP1 was shown. Still, the antimicrobial activity of these supernatants appeared to be more efficient, by $6 \%$, than the supernatant of pure lyophilized culture (Fig. 3). Several mechanisms have been proposed for bifidobacteria inhibiting pathogens including strains of Escherichia,

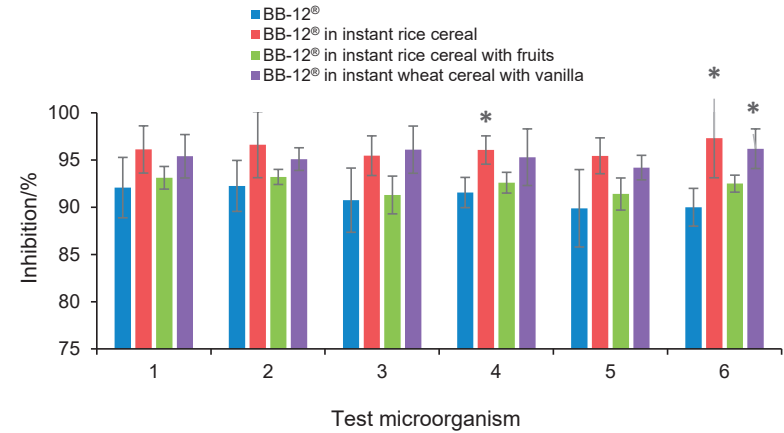

Fig. 3. Antibacterial activity of cell-free supernatants of Bifidobacterium animalis ssp. lactis $\mathrm{BB}-12^{\oplus}$ with and without wheat/rice cereal products after $24 \mathrm{~h}$ of incubation against test microorganisms: $1=S$. aureus 3048, 2=S. aureus K-11, 3=E. coli 3014, 4=S. enterica serovar Typhimurium FP1, 5=B. cereus TM2, 6=B. subtilis ATCC 6633. The results are expressed as mean value of three independent experiments and error bars represent standard deviation. *Significantly different $(p<0.01)$ from the $B B-12^{\circledR}$ without cereal product

Salmonella, Bacillus and Listeria: lowering of $\mathrm{pH}$ due to organic acid production, inhibitory activity of undissociated molecules of organic acids, competition for nutrients or adhesion sites, stimulation of immunosystem and production of bacteriocins (31,32). According to Cheikhyoussef et al. (33), BB-12 ${ }^{\circledR}$ strain produces bacteriocin Bifilact BB-12 ${ }^{\circledR}$ with antimicrobial activity against S. aureus, E. coli, S. enterica serovar Typhimurium and Listeria sp. Bifidobacteria showed high growth rates in rich synthetic media but also grew in simple media containing only lactose, free amino acids and some nucleotides, vitamins and minerals because the control of magnesium, manganese and iron levels is essential for optimal growth of bifidobacteria or bacteriocin production as a result of nutritional stress or induction. In addition, many strains of bifidobacteria can utilize complex biopolymers to improve cell growth and production of antimicrobials. These are mainly carbohydrates metabolized by bifidobacteria, but not by the host or other bacteria and are often used as prebiotics (34). Finally, dietary fibre has also been found to be effective in promoting intestinal growth of bifidobacteria and influence their antimicrobial production, so infant food matrices used here may have a potential to induce bacteriocin production. However, some bacteriocins may affect probiotic cultures so this must be considered when selecting bacteriocin-producing strain for inclusion in functional foods (35-37). Furthermore, besides bacteriocins, some other proteins, encoded by genes present in B. animalis ssp. lactis genome, which are involved in 
the BB- $12^{\circledR}$ adaptation to and survival in the human GIT, could also be related to its antimicrobial potential. Specifically, two paralogues encoding putative $\mathrm{N}$-acetylmuramidases, which are probably involved in the degradation of enteropathogen bacterial cell wall components, are present in the BB-12 ${ }^{\circledR}$ genome, as well as genes encoding putative cell surface proteins that could be involved in the interactions with human epithelial cells and consequently in competitive exclusion undesirable bacteria. Moreover, Bifidobacterium species, besides the production of lactate, also synthesise acetate, one of the major SCFA, important for growth and differentiation of colonocytes, which accounts for more than $80 \%$ of the SCFA production in the infant gut, and is a key metabolite in the early establishment of colonization resistance by preventing infections with enteropathogens (30). Indirectly, through a metabolic cross-feeding, where the metabolic products of a species or group of species provide growth substrates for other populations, production of acetate by Bifidobacterium sustains the growth of other favourable species that have a potential to inhibit enteropathogens.

Adhesion to intestinal epithelial cells is important for the colonization of probiotic strains in the GIT since it prevents their removal due to intestinal peristalsis and enables a competitive advantage over other bacteria. Prerequisite for the adhesion of probiotic strains to intestinal epithelial cells is the autoaggreation. Autoaggregation of BB- $12^{\circledR}$ cells from lyophilized pure culture and in the wheat/rice cereal products was examined (Fig. 4). Namely, probiotic bacteria that demonstrate coaggregation efficiency together with antimicrobial activity could represent an obstacle for the colonization of pathogenic microorganisms. In addition, coaggregation with

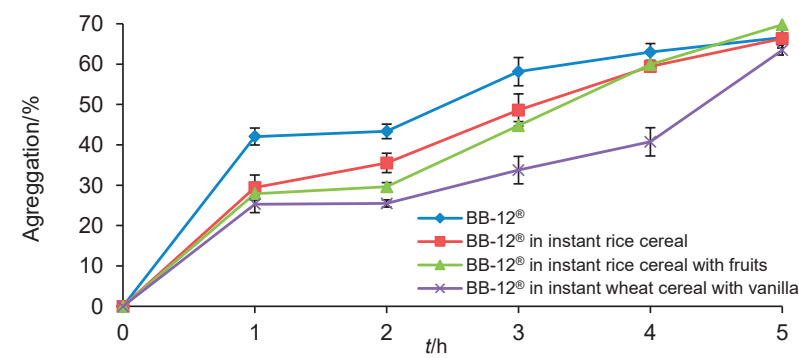

Fig. 4. Comparison of the autoaggregation ability of Bifidobacterium animalis ssp. lactis BB-12 ${ }^{\circledR}$ cells with and without wheat/rice cereal products resuspended in phosphate buffered saline $(\mathrm{pH}=7.2)$. The results are expressed as mean values of three independent experiments and error bars represent standard deviations other $\mathrm{LAB}$ that tolerate low $\mathrm{pH}$ could promote colonization of bifidobacteria in the intestine. Therefore, coaggregation of BB-12 ${ }^{\circledR}$ strain with $\mathrm{LAB}$ representatives, e.g. Lactobacillus helveticus M92 and Enterococcus faecium L3, and with test microorganisms Salmonella Typhimurium FP1 and E. coli 3014 was investigated (Table 2). Autoaggregation and coaggregation of BB- $12^{\circledR}$ was monitored during $5 \mathrm{~h}$. Although autoaggregation of lyophilized pure BB- $12^{\circledR}$ culture was higher in the first $4 \mathrm{~h}$ of incubation than the autoaggregation of BB- $12^{\circledR}$ cultures recovered from wheat/rice cereal products at the 5 th hour, which was the last hour of experiment, the autoaggregation percentage ( $>60 \%$ ) among all tested samples did not significantly differ. Coaggregation properties of lyophilized pure BB$-12^{\circledR}$ culture and cultures isolated from instant rice cereal and instant wheat cereal with vanilla were equally efficient either with Lactobacillus helveticus M92 or Enterococcus faecium L3 or the applied test microorganisms. The difference is observed with Salmonella Typhimurium FP1, where coaggregation with lyophilized pure BB-12 ${ }^{\circledR}$ culture was about $10 \%$ higher than with $B B-12^{\circledast}$ isolated from instant rice cereal with fruit. Coaggregation ability of BB- $12^{\circledR}$ from all the samples with two LAB was more obvious, and it increased approx. $20 \%$ compared with test microorganisms. Autoaggregation and coaggregation prevent the colonization of pathogens on surfaces, as they are involved in the second phase of biofilm formation. Numerous investigations have verified the beneficial effect of probiotic strains in biofilm form, including e.g. increased resistance to temperature or gastric $\mathrm{pH}$ (38). Falagas and Makris (39) proposed using probiotic LAB strains as excellent candidates to form protective biofilms and to even be part of daily cleaning products to lower the incidence of pathogenic microorganisms. Accordingly, Gómez et al. (40) reported the potential of probiotic LAB biofilms to control L. monocytogenes, S. Typhimurium and E. coli O157:H7 biofilm formation.

Immobilised mucin and monolayer culture of Caco-2 cells are model systems commonly used for the testing of probiotic strain adhesion (23). Hence, Caco-2 cells were used to test the adherence capacity of probiotic strain BB-12 ${ }^{\circledR}$. The adhesion ability of the probiotic BB-12 ${ }^{\circledR}$ strain to anchor and colonize human epithelial intestinal cell monolayer was investigated using Caco-2 cell line. Fig. 5a shows representative staining of Caco-2 nuclei (blue) together with adhered BB-12 ${ }^{\circledR}$ cells (green) using EV in instant wheat cereal with vanilla OS FLc Cell Imager (Thermo Fisher Scientific). Adhesion of BB-12 ${ }^{\circledR}$

Table 2. Coaggregation ability of Bifidobacterium animalis ssp. lactis BB-12 ${ }^{\circledR}$ with and without wheat/rice cereal products after $5 \mathrm{~h}$ of incubation in phosphate-buffered saline $(\mathrm{pH}=7.2)$ at room temperature

\begin{tabular}{lcccc} 
Microorganism & \multicolumn{4}{c}{ Coagreggation/\% } \\
\cline { 2 - 5 } Lactobacillus helveticus M92 & $\mathrm{BB}-12^{\odot}$ & $\mathrm{BB}-12^{\odot}(\mathrm{IRC})$ & $\mathrm{BB}-12^{\odot}(\mathrm{IRCF})$ & $\mathrm{BB}-12^{\odot}(\mathrm{IWC})$ \\
Enterococcus faecium L3 & $(53.7 \pm 1.3)^{\mathrm{az}}$ & $(50.51 \pm 0.8)^{\mathrm{bz}}$ & $(55.32 \pm 2.2)^{\mathrm{az}}$ & $(49.56 \pm 0.5)^{\mathrm{bz}}$ \\
Salmonella Typhimurium FP1 & $(41.4 \pm 0.5)^{\mathrm{by}}$ & $(42.50 \pm 0.7)^{\mathrm{by}}$ & $(45.87 \pm 0.8)^{\mathrm{ay}}$ & $(37.84 \pm 1.2)^{\mathrm{cy}}$ \\
Escherichia coli 3014 & $(34.5 \pm 1.1)^{\mathrm{ax}}$ & $(30.58 \pm 0.9)^{\mathrm{bx}}$ & $(25.67 \pm 1.3)^{\mathrm{cx}}$ & $(35.72 \pm 0.8)^{\mathrm{ax}}$ \\
\hline
\end{tabular}

$\mathrm{IRC}=$ instant rice cereal, IRCF=instant rice cereal with fruit, IWC=instant wheat cereal with vanilla. Results are mean value \pm standard deviation of

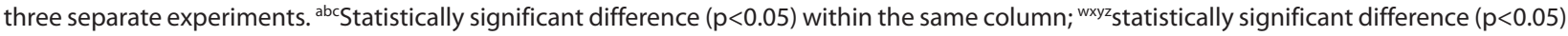
within the same row 
a)
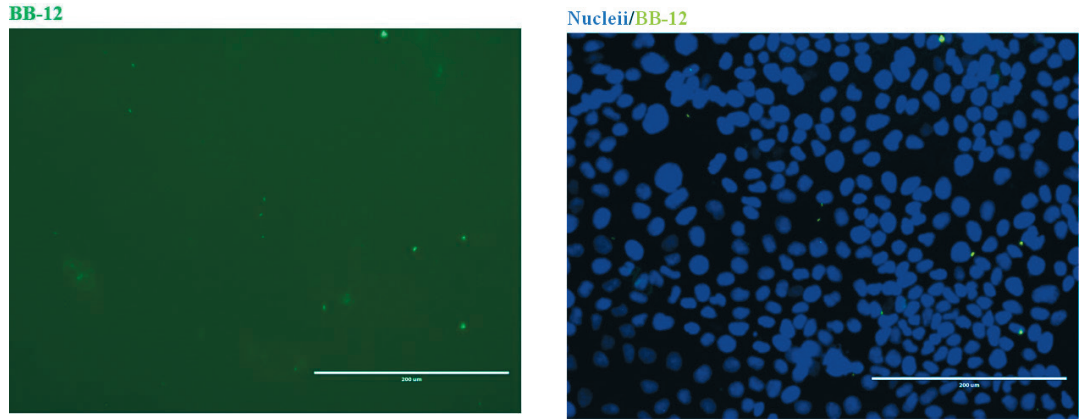

b)
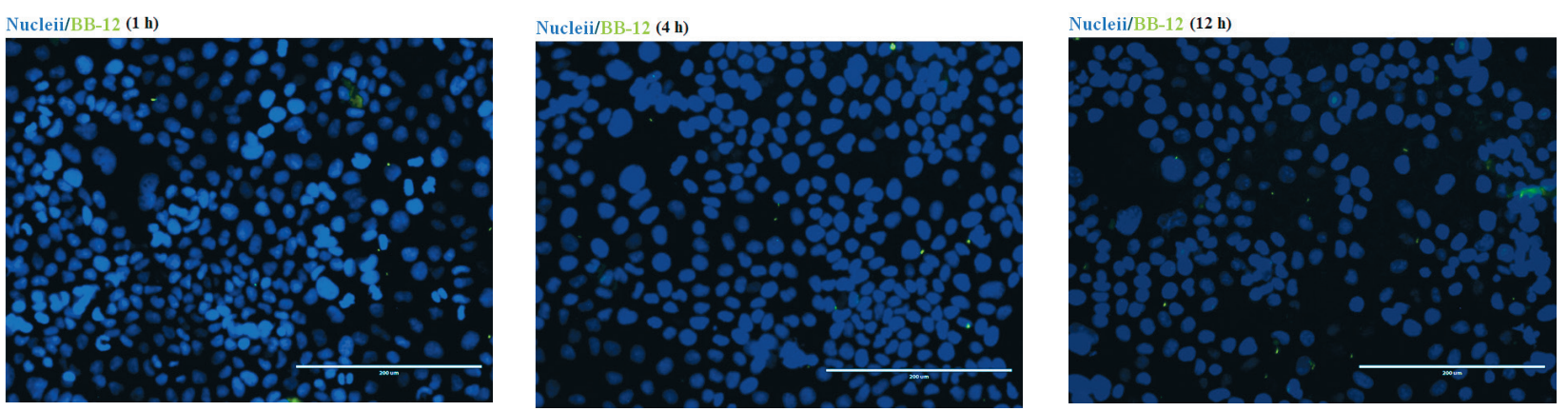

c)
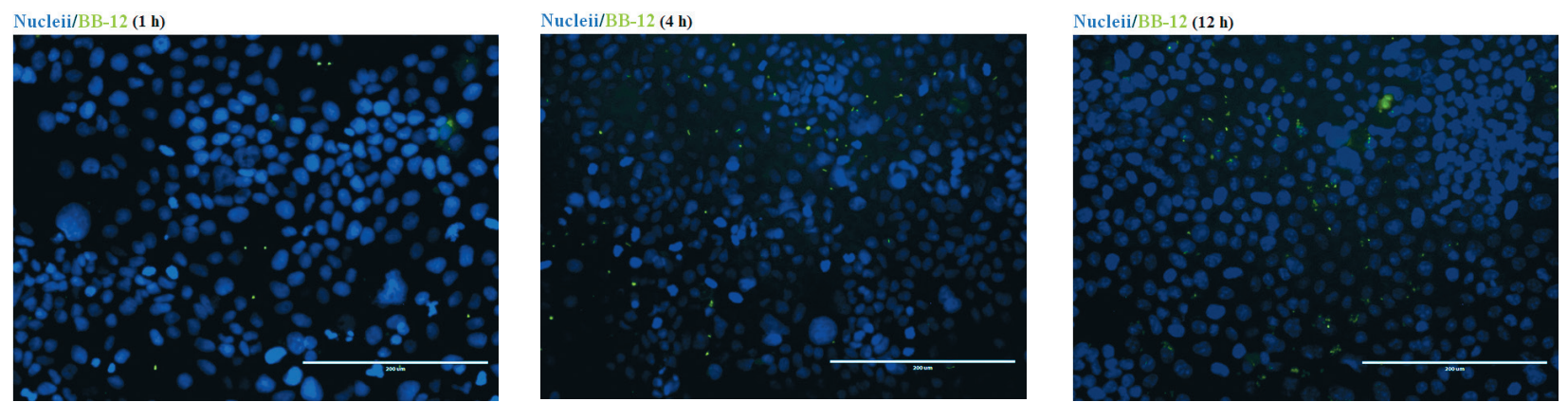

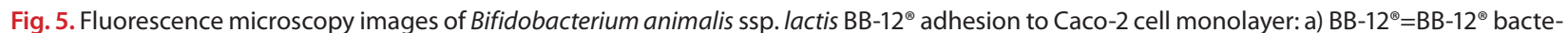
rial cells (green fluorescence), nuclei/BB-12 ${ }^{\oplus}=$ dual fluorescence overlays of Caco- 2 cell nuclei (blue fluorescence) and BB-12 ${ }^{\circledR}$ bacterial cells (green fluorescence). Fluorescence overlays of Caco-2 cell nuclei (blue fluorescence) with adhered BB-12 ${ }^{\circledast}$ bacterial cells (green fluorescence) at different seeding density: b) multiplicity of infection 10, and c) multiplicity of infection 100, after 1, 4 and $12 \mathrm{~h}$ of incubation at 20x magnification

to the Caco-2 cell monolayer at MOI 10 (Fig. 5b) and MOI 100 (Fig. $5 \mathrm{c}$ ) after 1, 4 and $12 \mathrm{~h}$ incubation is shown. The higher number of $\mathrm{BB}-12^{\circledR}$ cells adhered to Caco- 2 cell monolayer with the increase of $\mathrm{MOI}$ at longer incubation time. Accordingly, the highest BB- $12^{\circledR}$ adhesion capacity was achieved at $\mathrm{MOI} 100$ and after $12 \mathrm{~h}$ of incubation, when autoaggregates of BB- $12^{\circledR}$ cells were observed and the ratio of adhered probiotic bacterial cells to Caco-2 cells was 35:100 (Fig. $5 \mathrm{C}$ ). This is in line with a high aggregation capability of BB- $12^{\circledR}$ as shown in Fig. 4. Next, in order to evaluate the potential effect of the indigestible resistant starch, available in colon, on BB-12 ${ }^{\circledR}$ adhesion, the binding of the BB- $12^{\circledR}$ to Caco- 2 cell line was assessed with the addition of two different starch mass fractions ( 1 and $10 \%$ ). The difference in BB-12 ${ }^{\circledR}$ binding to Caco-2 cells was not significant in the presence (number of adhered
BB- $12^{\circledR}$ cells was $2.95 \cdot 10^{7}$ or $2.84 \cdot 10^{7} \mathrm{CFU} / \mathrm{mL}$, respectively) or absence $\left(4.43 \cdot 10^{7} \mathrm{CFU} / \mathrm{mL}\right)$ of two different starch mass fractions (data not shown).

The adhesion of BB- $12^{\oplus}$ cells to human collagen, fibronectin and laminin (Fig. 6) was analysed, since extracellular matrix (ECM) is a complex structure composed of the respective proteins, surrounding the intestinal epithelial cells (41). BB-12 ${ }^{\circledR}$ adhesion to fibronectin and collagen was more effective than to laminin, whereas no significant difference was observed between fibronectin and collagen. Protein nature of adhesive receptors on the bacterial cell surface was tested by prior proteinase $\mathrm{K}$ treatment of the examined cells. The adhesion mediators to ECM are probably of nonproteinaceous nature, implying that other surface molecules are probably involved in the bacterial adhesion, with an exception of collagen, where 


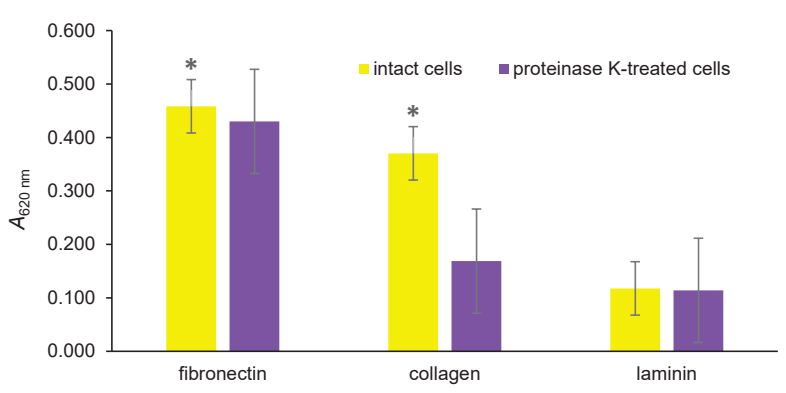

Fig. 6. Effects of proteinase K treatment on the binding of Bifidobacterium animalis ssp. lactis $\mathrm{BB}-12^{\circledR}$ cells to immobilised extracellular matrix proteins: fibronectin, collagen and laminin. The results are mean value of three independent experiments and error bars represent standard deviations. *Significantly different $(p<0.01)$ in comparison to laminin binding

the BB-1 ${ }^{\circledR}$ adhesion capacity was significantly interrupted after proteinase $\mathrm{K}$ treatment of the bacterial cells. Namely, the predicted functions encoded by bifidobacterial genome sequences provide genetic evidence that bifidobacteria are very well adapted to colonize the (human) GIT (42). The results, hence, could be correlated with the presence of $c a p A$ and $c a p B$ genes encoding putative collagen adhesion proteins in $\mathrm{BB}-12^{\circledR} \mathrm{ge}-$ nome. Additionally, although slight decrease of adhesion was observed after the proteinase $\mathrm{K}$ treatment in fibronectin binding experiment, the $f b p$ gene encoding a fibronectin-binding protein was also present in BB- $12^{\circledR}$ genome. Both collagen- and fibronectin-binding proteins are involved in the interactions with human epithelial cells $(43,44)$. Collectively, Bifidobacterium species possess important strategies that ensure their colonization at high abundance in the infant gut, prevention of the growth of competing species that are disturbing host microbiota balance and promotion of immune development (32).

The capability of probiotic bacteria to adhere to the human epithelial cells or mucosa is due to their ability to block the adhesion sites for pathogens (45). The effect is associated with the properties of the probiotic strain and the pathogen adherence ability. Using Caco-2 cell line, the number of adherent BB-12 ${ }^{\circledR}$ cells prior to adding the pathogens and the competence to exclude the adhesion of pathogens was examined. Approximately $5 \cdot 10^{6} \mathrm{CFU} / \mathrm{mL}$ of $3 \cdot 10^{9} \mathrm{CFU} / \mathrm{mL}$ added BB-12 ${ }^{\circledR}$ cells adhered to Caco-2 cells. Exclusion assay was executed in order to assess whether or not the preincubated probiotic strain is able to prevent pathogen adhesion to epithelial cells. The results signify that the adherence of BB-12 ${ }^{\circledR}$ strain to Caco- 2 cell line reduces the attachment of $S$. Typhimurium FP1 for approx. 1.5 $\log$ CFU/mL $(p<0.05)$, whereas the invasion of E. coli 3014 cells was not noticeably discernible (approx. $0.71 \mathrm{log}$ CFU/mL) (data not shown). Considering the beforehand obtained adhesion pattern, proved by live cell imaging microscope together with exclusion capacity, and coaggregation with examined pathogens, BB- $12^{\circledR}$ probiotic strain has an impact on the adhesion ability and could downsize the negative effects of both strains, S. Typhimurium FP1 and E. coli 3014.

\section{CONCLUSIONS}

PCR with Bifidobacterium strain-specific primers and AFLP DNA fingerprints confirmed the presence of BB- $12^{\circledR}$ strain in newly developed wheat/rice cereal infant products, where the determined probiotic bacterial counts were above $10^{6}$ $\mathrm{CFU} / \mathrm{g}$, as requested for probiotic products by FAO/WHO. Significantly higher viable cell counts were observable after probiotic cell exposure in simulated gastrointestinal conditions when probiotic culture BB- $12^{\circledR}$ was used in processed wheat/rice cereal products than of lyophilized pure culture. Aggregation ability, adhesion to extracellular matrix proteins and intestinal epithelial Caco-2 cells together with antibacterial activity emphasized competitive exclusion of strains $S$. Typhimurium FP1 and E. coli 3014 from Caco-2 cells by probiotic strain BB-12 ${ }^{\circledR}$. Wheat/rice cereal products enriched with a lyophilized probiotic culture positively influenced cholesterol assimilation by $\mathrm{BB}-12^{\circledR}$ strain. Altogether, the results suggest reciprocal beneficial effects resulting from the positive influence of the pilot-scale processed wheat/rice cereal products on the specific probiotic properties of $\mathrm{BB}-12^{\circledR}$ strain, while the incorporation of the BB- $12^{\circledast}$ brought potential added functional value to a novel product.

\section{ACKNOWLEDGEMENTS}

This research was funded by Ministry of Science and Education of the Republic of Croatia (Project No. 0581990 'Probiotics, prebiotics and functional starter cultures') and Podravka d.d., Koprivnica, Croatia. Adhesion experiments were supported by the Croatian Science Foundation through the project IP-2014-09-7009.

\section{ORCID IDs}

A. Leboš Pavunc (1) https://orcid.org/0000-0002-4954-7133

L. Penava (1) https://orcid.org/0000-0002-1828-5441

J. Ranilović (iD https://orcid.org/0000-0001-7600-1083

J. Novak (D) https://orcid.org/0000-0003-1374-1097

M. Banić (i) https://orcid.org/0000-0002-0509-8284

K. Butorac (1) https://orcid.org/0000-0002-1682-0703

E. Petrović (10 https://orcid.org/0000-0003-0228-6834

V. Mihaljević-Herman (1) https://orcid.org/0000-0002-6111-498X

K. Bendelja (1) https://orcid.org/0000-0002-6017-3355

A. Savić Mlakar (1) https://orcid.org/0000-0003-4679-3563

K. Durgo (1) https://orcid.org/0000-0002-9488-3873

B. Kos (i) https://orcid.org/0000-0003-1711-316X

J. Šušković (i) https://orcid.org/0000-0002-9790-3008

\section{REFERENCES}

1. Hill C, Guarner F, Reid G, Gibson GR, Merenstein DJ, Pot B, et al. The international scientific association for probiotics and prebiotics consensus statement on the scope and appropriate use of the term probiotic. Nat Rev Gastroenterol Hepatol. 2014;11:506-14.

https://doi.org/10.1038/nrgastro.2014.66 
2. Ashraf R, Shah NP. Antibiotic resistance of probiotic organisms and safety of probiotic dairy products. Int Food Res J. 2011;18(3):837-53.

3. Chatterjee S, Kar P, Das T, Ray S, Ganguly S, Rajendiran C, Mitra M. Randomised placebo-controlled double blind multicentric trial on efficacy and safety of Lactobacillus acidophilus LA-5 and Bifidobacterium BB-12 for prevention of antibiotic-associated diarrhoea. J Assoc Phzsicians India. 2013;61(10):708-12.

4. Jungersen M, Wind A, Johansen E, Christensen JE, Stuer-Lauridsen $B$, Eskesen $D$. The science behind the probiotic strain Bifidobacterium animalis subsp. lactis BB-12 ${ }^{\circledR}$. Microorganisms. 2014;2(2):92-110.

https://doi.org/10.3390/microorganisms2020092

5. Vinderola G, Binetti A, Burns P, Reinheimer J. Cell viability and functionality of probiotic bacteria in dairy products. Front Microbiol. 2011;2(70):Article No. 70.

https://doi.org/10.3389/fmicb.2011.00070

6. Michail S. The role of probiotics in allergic diseases. Allergy Asthma Clin Immunol. 2009;5(1):5. https://doi.org/10.1186/1710-1492-5-5

7. Ottman N, Smidt H, de Vos WM, Belzer C. The function of our microbiota: Who is out there and what do they do? Front Cell Infect Microbiol. 2012;2:Article No. 104.

https://doi.org/10.3389/fcimb.2012.00104

8. Kirjavainen PV, Arvola T, Salminen SJ, Isolauri E. Aberrant composition of gut microbiota of allergic infants: A target of bifidobacterial therapy at weaning? Gut. 2002;51(1):51-5. https://doi.org/10.1136/gut.51.1.51

9. Taipale T, Pienihäkkinen K, Isolauri E, Larsen C, Brockmann E, Alanen $\mathrm{P}$, et al. Bifidobacterium animalis subsp. lactis BB-12 in reducing the risk of infections in infancy. Br J Nutr. 2011; 105(3):409-16.

\section{https://doi.org/10.1017/S0007114510003685}

10. Garrigues C, Johansen E, Pedersen MB. Complete genome sequence of Bifidobacterium animalis subsp. lactis BB-12, a widely consumed probiotic strain. J Bacteriol. 2010;192(9): 2467-8.

https://doi.org/10.1128/JB.00109-10

11. Hajduk G, Kos B, Šušković J, Frece J, Leboš A, Beganović J. Probiotic properties of Bifidobacterium animalis subsp. lactis BB-12 in baby cereal flakes enriched with inulin. Ital J Food Sci. 2009;21(4):473-86.

12. Gardiner GE, Heinemann C, Bruce AW, Beuerman D, Reid G. Persistence of Lactobacillus fermentum RC-14 and Lactobacillus rhamnosus GR-1 but not Lactobacillus rhamnosus GG in the human vagina as demonstrated by randomly amplified polymorphic DNA. Clin Diagn Lab Immunol. 2002;9(1): 92-6.

https://doi.org/10.1128/CDLI.9.1.92-96.2002

13. Kaufmann P, Pfefferkorn A, Teuber M, Miele L. Identification and quantification of Bifidobacterium species isolated from food with genus specific 16S r RNA-targeted probes by colony hybridization and PCR. Appl Environ Microbiol. 1997; 63(4):1268-73.

14. Leboš Pavunc A, Beganović J, Kos B, Uroić K, Blažić M, Šušković J. Characterization and application of autochthonous starter cultures for fresh cheese production. Food Technol Biotechnol. 2012;50(2):141-51.

15. Michener CD, Sokal, RR. A quantitative approach to a problem in classification. Evolution.1957:11(2):130-62.

https://doi.org/10.2307/2406046

16. Liong MT, Shah NP. Optimization of cholesterol removal, growth and fermentation patterns of Lactobacillus acidophilus ATCC 4962 in the presence of mannitol, fructo-oligosaccharide and inulin: A response surface methodology approach. J Appl Microbiol. 2005;98(5):1115-26. https://doi.org/10.1111/j.1365-2672.2005.02544.x

17. Uroić K, Nikolić M, Kos B, Leboš Pavunc A, Beganović J, Lukić $\mathrm{J}$, et al. Probiotic properties of lactic acid bacteria isolated from Croatian fresh soft cheeses and Serbian white-pickled cheeses. Food Technol Biotechnol. 2014;52(2):232-41.

18. Leboš Pavunc A, Kos B, Beganović J, Uroić K, Bučan D, Šušković J. Antibiotic susceptibility and antimicrobial activity of autochthonous starter cultures as safety parameters for fresh cheese production. Mljekarstvo. 2013:63(4):185-94.

19. Kos B, Šušković J, Beganović J, Gjuračić K, Frece J, lannaccone $C$, Canganella F. Characterization of the three selected probiotic strains for the application in food industry. World J Microbiol Biotechnol. 2008;24(5):699-707 https://doi.org/10.1007/s11274-007-9528-y

20. Beganović J, Leboš Pavunc A, Gjuračić K, Špoljarec M, Šušković J, Kos B. Improved sauerkraut production with probiotic strain Lactobacillus plantarum L4 and Leuconostoc mesenteroides LMG 7954. J Food Sci. 2011;76(2):M124-9. https://doi.org/10.1111/j.1750-3841.2010.02030.x

21. Kos B, Šušković J, Vuković S, Šimpraga M, Frece J, Matošić S. Adhesion and aggregation ability of probiotic strain Lactobacillus acidophilus M92. J Appl Microbiol. 2003;94(6):981-7. https://doi.org/10.1046/j.1365-2672.2003.01915.x

22. Uroić K, Novak J, Hynönen U, Pietilä TE, Leboš Pavunc A, Kant $\mathrm{R}$, et al. The role of $\mathrm{S}$-layer in adhesive and immunomodulating properties of probiotic starter culture Lactobacillus brevis D6 isolated from artisanal smoked fresh cheese. LWT - Food Sci Technol. 2016;69:623-32. https://doi.org/10.1016/j.lwt.2016.02.013

23. Banić M, Uroić K, Leboš Pavunc A, Novak J, Zorić K, Durgo K, et al. Characterization of S-layer proteins of potential probiotic starter culture Lactobacillus brevis SF9B isolated from sauerkraut. LWT - Food Sci Technol. 2018;93:257-67. https://doi.org/10.1016/j.lwet.2018.03.054

24. One-way ANOVA, VassarStats: Website for Statistical Computation, Vassar College, Poughkeepsie, NY USA; 2019. Available from: http://vassarstats.net/. 
25. Shah NP. Functional cultures and health benefits. Int Dairy J. 2007;17(11):1262-77.

https://doi.org/10.1016/j.idairyj.2007.01.014

26. Joint FAO/WHO Expert consultation on evaluation of health and nutritional properties of probiotics in food including power milk with live lactic acid bacteria. Amerian Córdoba Park Hotel, Córdoba, Argentina, 1-4 October 2001. Available from: http://www.fao.org/tempref/docrep/fao/meeting/009/y6398e.pdf.

27. EFSA Panel on Additives and Products or Substances used in Animal Feed (FEEDAP). Guidance on the assessment of bacterial susceptibility to antimicrobials of human and veterinary importance. EFSA J. 2012;10(6):2740.

https://doi.org/10.2903/j.efsa.2012.2740

28. Ashraf R, Shah NP. Antibiotic resistance of probiotic organisms and safety of probiotic dairy products. Int Food Res J. 2011;18(3):837-53.

29. Dos Santos CS, Hoch Batista de Souza C, Padilha M, Gioielli LA, Neves Rodrigues Ract J, Isay Saad SM. Milk fat protects Bifidobacterium animalis subsp. lactis $\mathrm{Bb}-12$ from in vitro gastrointestinal stress in potentially synbiotic table spreads. Food Funct. 2019;9(8):4274-81.

https://doi.org/10.1039/c8fo00506k

30. Ruiz L, Margolles A, Sánchez B. Bile resistance mechanisms in Lactobacillus and Bifidobacterium. Front Microbiol. 2013; 396(4):Article No. 396.

https://doi.org/10.3389/fmicb.2013.00396

31. Fukuda S, Toh H, Hase K, Oshima K, Nakanishi Y, Yoshimura $\mathrm{K}$, et al. Bifidobacteria can protect from enteropathogenic infection through production of acetate. Nature. 2011;469: 543-7.

https://doi.org/10.1038/nature09646

32. Laforest-Lapointe I, Arrieta MC. Patterns of early-life gut microbial colonization during human immune development: An ecological perspective. Front Immunol. 2017;8:Article No. 788.

\section{https://doi.org/10.3389/fimmu.2017.00788}

33. Cheikhyoussef A, Pogori N, Chen, H, Tian F, Chen W, Tang J, Zhang $\mathrm{H}$. Antimicrobial activity and partial characterization of bacteriocin-like inhibitory substances (BLIS) produced by Bifidobacterium infantis BCRC 14602. Food Control 2009; 20(6):553-9.

https://doi.org/1016/j.foodcont.2008.08.003.

34. Castillo Martinez FA, Balciunas EM, Converti A, Cotter A, de Souza Oliveira RP. Bacteriocin production by Bifidobacterium spp. A review. Biotechnol Adv. 2013;31(4):482-8. https://doi.org/10.1016/j.biotechadv.2013.01.010

35. O’Bryan CA, Koo OK, Sostrin ML, Ricke SC, Crandall PG, Johnson MG. Characteristics of bacteriocins and use as food antimicrobials in the United States. In: Ricke SC, Atungulu GG, Rainwater CE, Park SH, editors. Food and feed safety systems and analysis. Cambridge, MA, USA: Academic Press-Elsevier; 2018. pp. 273-86.

https://doi.org/10.1016/B978-0-12-811835-1.00015-4

36. Smigic N, Miocinovic J, Tomic J, Tomasevic I, Rajkovic A, Djekic I. The effect of nisin and storage temperature on the quality parameters of processed cheese. Mljekarstvo. 2018; 68(3):182-91.

https://doi.org/10.15567/mljekarstvo.2018.0303

37. Čanak I, Markov K, Melvan E, Starčević A, Živković M, Zadravec $M$, et al. Isolation and characterisation of $L$. plantarum 01 producer of plantaricin as potential starter culture for the biopreservation of aquatic food products. Food Technol. Biotechnol. 2018;56(4):581-9.

https://doi.org/10.17113/ftb.56.04.18.5707

38. Salas-Jara MJ, Ilabaca A, Vega M, Garcia A. Biofilm forming Lactobacillus: New challenges for the development of probiotics. Microorganims. 2016;4(35):1-14.

https://doi.org/10.3390/microorganisms4030035

39. Falagas ME, Makris GC. Probiotic bacteria and biosurfactants for nosocomial infection control: A hypothesis. J Hosp Infect. 2009;71(4):301-6.

https://doi.org/10.1016/j.jhin.2008.12.008

40. Gómez NC, Ramiro JMP, Quecan BXV, de Melo Franco BDG. Use of potential probiotic lactic acid bacteria (LAB) biofilms for the control of Listeria monocytogenes, Salmonella Typhimurium, and Escherichia coli O157:H7 biofilms formation. Front Microbiol. 2016;7:Article No. 863.

https://doi.org/10.3389/fmicb.2016.00863

41. Lea T. Caco-2 Cell Line. In: Verhoeckx K, Cotter P, López-Expósito I, Kleiveland C, Lea T, Mackie A, Raquena T, et al., editors. The impact of food bioactives on health. Cham, Switzerland: Springer; 2015. pp. 103-11.

https://doi.org/10.1007/978-3-319-16104-4_10

42. Pokusaeva K, Fitzgerald GF, van Sinderen D. Carbohydrate metabolism in Bifidobacteria. Genes Nutr. 2011;6(3): 285-306.

https://doi.org/10.1007/s12263-010-0206-6

43. Barrangou R, Briczinski EP, Traeger LL, Loquasto JR, Richards $M$, Horvath $P$, et al. Comparison of the complete genome sequences of Bifidobacterium animalis subsp. lactis DSM 10140 and BI-04. J Bacteriol. 2009;191(13):4144-51.

https://doi.org/10.1128/JB.00155-09

44. Gilad O, Svensson B, Viborg AH, Stuer-Lauridsen B, Jacobsen S. The extracellular proteome of Bifidobacterium animalis subsp. lactis BB-12 reveals proteins with putative roles in probiotic effects. Proteomics. 2011;11(12):2503-14.

https://doi.org/10.1002/pmic.201000716

45. Garcia-Gonzales N, Prete R, Battista N, Corsetti A. Adhesion properties of food-associated Lactobacillus plantarum strains on human intestinal epithelial cells and modulation of IL-8 release. Front Microbiol. 2018;9:Article No. 2392. https://doi.org/10.3389/fmicb.2018.02392 